\title{
A COMPARISON OF NUTRITIONAL KNOWLEDGE AND FOOD HABITS OF COLLEGIATE AND NON-COLLEGIATE ATHLETES
}

\author{
Hamid Arazi ${ }^{1}$ and Rastegar Hosseini ${ }^{1}$ \\ ${ }^{1}$ Faculty of Sport Sciences, University of Guilan, Iran
}

\begin{abstract}
SUMMARY
Nutrition is an important component of any physical fitness program. The main dietary goal for active individuals is to obtain adequate nutrition to optimize health fitness and to increase sports performance. The purpose of this study was to compare nutritional knowledge and food habits in collegiate $s$ and non-collegiate athletes. The target population of this study was all male and female collegiate and non-collegiate athletes in Rasht city of Iran. After translate of the standard nutrition knowledge and attitudes survey questionnaire Zawila et al., and adjust of some questions, questionnaire was evaluated by Professors of faculty of physical education and sport sciences. The reliability guided Cronbach Alpha value of .81. A researcher-built questionnaire which was developed to measure subject's nutrition knowledge and habits, distributed to 130 collegiate and non-collegiate athletes males and 120 Collegiate and non- collegiate athletes females randomly. The questionnaire contained 15 nutrition knowledge questions and 25 nutrition habits questions. The collected data was analyzed by $t$-test, one-way ANOVA and Pearson correlation coefficient $(p<.05)$. The correct response rate for the sport nutrition and general nutrition score were in collegiate athletes male $(57.15 ; 52.5 \%)$ and athletes female $(58.14 ; 54.85 \%)$; non-collegiate athlete's males $(41.55 ; 39.86 \%)$ and athletes female $(42.11 ; 40.66 \%)$ respectively. Also, mean nutrition scores in collegiate athlete's males and females were significantly higher than non-collegiate athletes male and females. Furthermore, there were significant differences in the total mean score questionnaire between collegiate and non-collegiate athletes $(p<$ $.05)$. Based on the result of our study the knowledge of Iranian non-collegiate athletes were lower than collegiate athletes. For this reason, nutrition knowledge and attitudes of Iranian non-collegiate athletes need to improve. So, these suggest that nutrition lectures' courses are one of the solutions to increase knowledge about nutrition.
\end{abstract}

Key Words: nutritional knowledge, attitudes, athletes.

\section{INTRODUCTION}

The study of nutrition dates back to over 200 years; however, sports nutrition is relatively a new discipline involving the application of nutritional principles to enhance the athletic performance. Nutrition affects a sportsman in many ways. At the basic level, it plays an important role in achieving and maintaining health. Optimal nutrition can reduce fatigue, allowing an athlete to train and compete longer or recover faster between training sessions (Lin \& Lee, 2005). Nutrition plays a very important role in attaining high level of achievements in sports.
Nutritional status has a direct bearing on the level of physical performance. Hence, physical fitness and training are very much dependent on nutritional status of sports personnel (Beals \& Manore, 1998). Nutrition is an important complement of any physical fitness program. The main dietary goal for active supplement information from nutritionists/dietitians and individuals is to obtain adequate nutrition to optimize health and fitness or sports performance (Ozdoğan \& Ozcelik, 2011). It is well recognized that optimal nutrition can enhance athletic performance. However, numerous barriers can hinder college athletes from achieving optimal dietary practices, inclu- 
ding a lack of time and space to prepare meals (in the confines of dormitories, apartments, or shared housing), insufficient financial resources, limited meal-planning and -preparation skills, and busy travel schedules (American College of Sports Medicine, 2000; Malinauskas et al., 2007). Studies show that individuals that have basic nutrition knowledge and attitude apply these principles when selecting foods and also indicated that Food faddism is one among many influencing factors on student food choices (Read \& Schlenker, 1993). Therefore, improving nutrition knowledge, attitude and dietary practices through nutritional education may help to prevent or mitigate the aforementioned diseases (Chang, 1987; Frederick \& Hawkins, 1992; Lissner \& Heitmann, 1995). A college athlete is an appropriate target audience for nutrition education because their lives are in transition and have the potential for positive changes (Yueching \& Yi-Chia, 1999). Several studies have reported that college students frequently have misconceptions about nutrition, fail to make nutrition a priority in food selection, and are poorly informed about dietary guidelines (Abood, Black, \& Birnbaum, 2004; Jacobson, Sobonya, \& Ransone, 2001; Mitchell, 1990).

However, Hassapidou, Fourtounopoulos, Efstratiou, Kitsou, and Papakitsos (2003) discovered, while studying Greek basketball players, that most of the knowledge and food habits given to athletes from their coaches was inaccurate information. Therefore, it is important for that working with athlete's to find ways to educate athletes on accurate and helpful dietary advice (Wiita, Stombaugh, \& Buch, 1995). In addition, research on the effects of nutrition education reported similar findings of improving an individual's knowledge and food habits and awareness, supporting the need for and the usefulness of nutrition education in increasing nutrition knowledge, self-efficacy, and positive change in perceptions about knowledge and food habits among a student (Kunkel, Bell, \& Luccia, 2001; Paschoal, \& Amancio 2004). Studies show that nutrition knowledge and attitudes have an effect on eating habits (Laurie, Zawila, \& Steibt, 2003; Ruka, Toyama, Amamoto, Liu, \& Shinfuku, 2005). Ruka et al. (2005) described, although $85.6 \%$ of students are aware of the concept of nutritionally balanced food, only a few numbers of students (7\%) apply this concept when selecting food from a menu. Moreover, only $51 \%$ of students showed a desire to learn about healthy diets (Ibid). Jacobson et al. (2001) survey results indicated that only 3, 11.7 and $29.5 \%$ correctly identified recommended percents of total calorie intake for protein, fat and carbohydrates, respectively; $37 \%$ correctly identified the role of vitamins and $54.4 \%$ for protein. Studies have indicated that males (85\%) and females $(87 \%)$ advised young overweight adolescents to diet to lose weight; $20 \%$ of females and $13 \%$ of male regularly skipped breakfast. The advice given showed a lack of specific nutrition education about weight control, adolescent's nutritional needs, and fat diet (O'dea, \& Abraham, 2001; Sakamaki, Toyama, Amamoto, Liu, \& Shinfuku, 2005). Nutrition knowledge presumably influences attitudes and eating behavior (Rosenbloom, Jonnalagadda, \& Skinner, 2002). There are many reasons why nutritional advice is not followed. It may be due to the lack of knowledge or information, and interest of making a change in one's diet, or certain perceived or encountered barriers that may prevent people from eating healthier diets such as the lack of money (cost), lack of time (too busy with work) or taste (Kearney \& McElhone, 1999). Athletes may often rely on coaches for nutrition guidance in certain sports. Therefore, when coaches are misinformed about nutrition, this becomes a potential problem for athletes, as well (Cotugna, Vickery, \& McBee, 2005). Nutrition training can be conveyed to the individuals through regular and wide educational programs as well as the individual training himself on his own settings (Yllmaz \& Özkan, 2007).

Unfortunately, many of these sources are not suitable, and at times the information imparted is unreliable and only adds to the myths surrounding nutrition that may affect athletes' diet (Barr, 1987). But, education and its relationship with nutrition knowledge and attitudes has not been well studied. Furthermore, Studies have indicated that college students appear to have positive attitudes toward nutrition (Jacobson et al., 2001; Ruka et al., 2005; Yueching \& Yi-Chia, 1999). In contrast to many other countries, Iranian schoolchildren do not receive any nutrition education as part of their school's routine curriculum, so when they become college athletes, they have a very limited nutrition knowledge base (Jessri, Jessri, RashidKhani, \& Zinn, 2010). This suggests that if the areas of knowledge deficits or reasons for nutritional choices can be identified, the college student will be receptive to nutrition education; and moreover, due to lack of enough information about nutritional knowledge and food habits of Athletes in Iran. The purpose of this study was to compare nutritional knowledge and food habits in collegiate and non-collegiate athletes (athletes who were competitive at national and regional levels). 


\section{METHODS}

We used standard questionnaire (Zawila, Steib, \& Hoogenboom, 2003) which was used by Barr (1987) and Chapman and Toma (1997) before. This questionnaire in order to study the nutritional knowledge and food habits of students is provided. First part of the questionnaire included personal information, and the second part contained 40 True and False questions. Questions related to nutritional knowledge's was contained: $\mathrm{CHO}$, Fat and Protein (five questions), fiber (two questions), general nutrition (nine questions),
Vitamins (seven questions), Calcium and ferrous (nine questions), sport nutrition (six questions) and weight lose (two questions). The Reliability of the questionnaire was provided by using Cronbach Alpha value of .81 (In statistics, Cronbach's (alpha) is a coefficient of internal consistency. It is commonly used as an estimate of the reliability of a psychometric test for a sample of examinees). 300 questionnaires randomly were distributed between male and female athletes. Out of these, 130 questionnaires for males and 120 questionnaires for females were completely filled out and returned. The collected

TABLE 1

Mean and standard deviation of age, height and weight of respondents.

\begin{tabular}{lccccccc}
\hline \multirow{2}{*}{ Respondent } & \multirow{2}{*}{$N$} & \multicolumn{2}{c}{ Age } & \multicolumn{3}{c}{ Height $(\mathrm{cm})$} & \multicolumn{2}{c}{ Weight (kg) } \\
\cline { 2 - 8 } & & $M$ & $S D$ & $M$ & $S D$ & $M$ & $S D$ \\
\hline Collegiate athlete males & 63 & 24.71 & 2.30 & 173.10 & 5.20 & 71.19 & 2.08 \\
\hline Non-collegiate athlete males & 67 & 23.42 & 1.80 & 170.18 & 3.44 & 74.59 & 4.80 \\
\hline Collegiate athlete females & 58 & 23.61 & 2.10 & 163.61 & 6.02 & 58.87 & 4.71 \\
\hline Non-collegiate athlete females & 62 & 21.49 & 2.80 & 159.98 & 5.60 & 56.78 & 7.22 \\
\hline
\end{tabular}

Legend: N - Number od respondent; $\mathbf{M}$ - Mean; SD - Standard deviation.

TABLE 2

Mean percentage of correct response to subgroups nutrition questions.

\begin{tabular}{lcccc}
\hline & \multicolumn{2}{c}{ Male } & \multicolumn{2}{c}{ Female } \\
\hline & Collegiate & Non-colegiate & Collegiate & Non-collegiate \\
\hline CHO, Fat and Protein & 59.60 & 38.40 & 61.60 & 43.20 \\
\hline Fiber & 53.30 & 45.10 & 59.00 & 52.00 \\
\hline Vitamin & 60.70 & 64.41 & 62.57 & 57.10 \\
\hline Calcium and Iron & 57.00 & 51.54 & 60.22 & 57.15 \\
\hline Weight Lose & 61.90 & 51.40 & 62.50 & 56.00 \\
\hline
\end{tabular}

data was analyzed by descriptive and deductive statics, Pearson correlation coefficient, t-student and one-way ANOVA.

\section{RESULTS}

Mean and standard deviation of age, height and weight were reported in Table 1 and mean percentage of correct response to subgroups nutrition questions were presented in Table 2. Figure 1 show correct response rate to general and sport nutrition questions. In all collected answers of general nutrition and sport nutrition, maximum mean of correct response percentage to general nutrition questions was related to collegiate athlete's females. The results show that collegiate athlete's females had highest score for question related to $\mathrm{CHO}$, Fat, Protein and weight lose and collegiate athlete's males had highest score for questions related to calcium, and ferrous subdivisions. The results of present research also indicate that correct response percentages of collegiate athlete's females were significantly higher than non-collegiate athlete's females $(p=.02)$ and collegiate athlete's males were significant higher than non-collegiate athlete's females $(p=.03)$, while this difference was not significant between collegiate athlete's females and collegiate athlete's males ( $p=.64$ ). Also, the results show, was no significant diference between non-collegiate athlete's females and non-collegiate athlete's males. In addition, the results show that there is significant and positive correlation between general nutrition and sport nutrition of male and 


\section{FIGURE 1}

Correct response rate to general and sport nutrition questions.

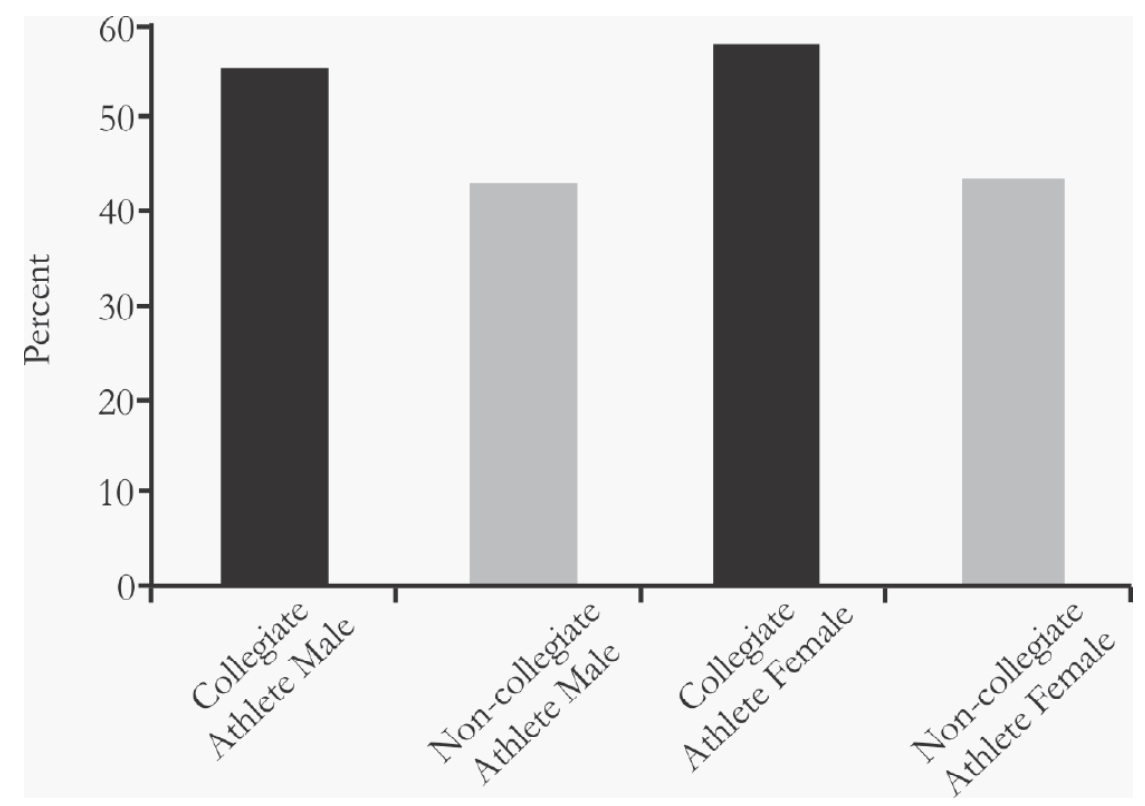

FIGURE 2

Correlation between general nutrition and sport nutrition of college athlete males.

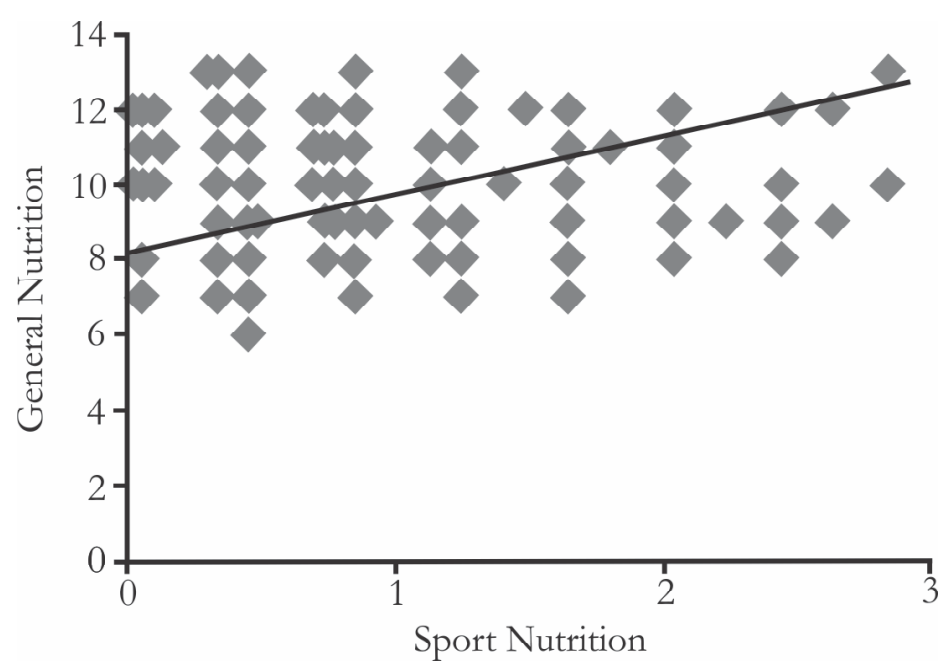

FIGURE 3

Correlation between general nutrition and sport nutrition of non-college athlete females.

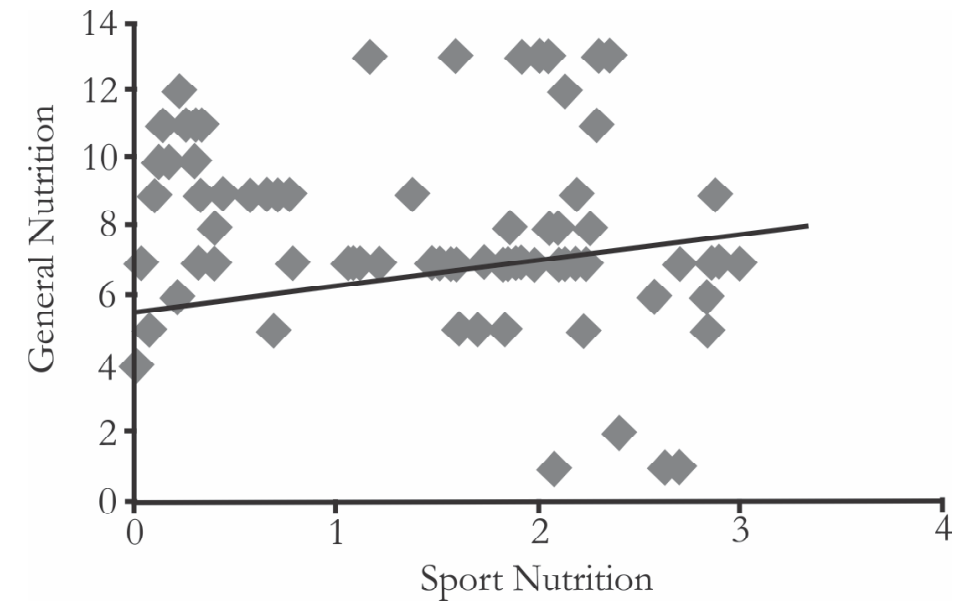


female collegiate athletes (Figure 2), while there was no significant correlation between general nutrition and sport nutrition of male and female non-collegiate athletes (Figure 3).

\section{DISCUSSION}

Recent research suggests that the adolescent athlete's is neither aware of nor prepared for the dual demands of sound nutritional practices in general, nor those demands by his or her chosen sport activities (Chapman \& Toma, 1997; Laurieet et al., 2003). College athletes have misconception about nutrition, and have poor nutrition knowledge and attitude (Nancy, Connie, Vickery, \& Mcbee, 2005; Schmalz, 1993). Also Studies show that athletes not knowledgeable enough about nutritional issues and their knowledge and attitude are in average level (Chang, 1987; Sakamaki et al., 2005).

The present study found that sport nutrition and general nutrition questions scores of male and female athletes studying in college was significantly higher than male and female non-college athletes. These data are similar to the study done by Chang, Georgia and Yoeching, which indicating that student's nutrition knowledge is related to their majors (Georgia et al., 1993; Yueching \& Yi-Chia, 1999). Azizi, Rahmani-Nia, Malaee, Malaee, and Khosravi (2010) and Georgia et al. (1993) indicated that nutritional knowledge is related to the individual field of study. The result shows that athletes varied in their nutrition knowledge depending on their college majors. The combination of two variable s- gender and Education type, influenced the total knowledge score in this study. The present study found that nutrition attitude scores of female collegiate athletes were significantly higher than female non-collegiate athletes. Also nutrition attitude scores of male collegiate athletes were higher than male non- collegiate athletes, but this difference was just between male and female collegiate athletes and male and female non-collegiate athletes was significant. Georgia et al. (1993) reported that nutrition knowledge was not related to gender. In contrast, we found that female athletes had a significantly higher knowledge and attitude score than male athletes. This is similar to Azizi et al. (2010) and Yoeching and Yi-Chia (1999) study, which indicated female students, had higher nutrition knowledge scores, and better nutrition attitude than male students. Dunn, Turner, and Denny (2007) found that female athletes scored slightly higher than their male counterparts on their nutritional knowledge questionnaire. As well as each recommendation section. In contrast, knowledge was reported to be the same in both genders in two other studies (Jessri et al., 2010; Rosenbloom et al., 2002). It suggests that females in general are more concerned about their nutrition and health than males.

The results of present study also indicate that correct response percentages of collegiate athletes were significant higher than non-collegiate athlete, while this difference was not significant between collegiate athlete's males and females. Previous studies demonstrated that athlete student who had completed a nutrition course in college scored higher on nutritional knowledge tests than those who had not (Barr, 1987; Laurie et al., 2003). However, related courses such as exercise physiology, sport nutrition and exercise science are required for collegiate athlete. A background in exercise physiology, sport nutrition and exercise science may be one of the reasons for better performances on the knowledge test, but possible relationship between nutrition knowledge, and these courses needs further investigation. Providing a nutrition or nutrition-related course to noncollegiate athletes may be one way to increase their nutrition knowledge and therefore, positively influence dietary behaviors. Previous studies found that collegiate athletes, who completed a nutrition course in college, demonstrated greater nutritional knowledge than those who did not complete a nutrition course (Barr, 1987; Laurie et al., 2003; Sakamaki et al., 2005). Our study's data support this finding, suggesting that student may benefit from taking a nutrition course or from receiving additional information for optimal health and performance.

Results also indicated correct response percentage in the CHO, Fat, Protein, Fiber, Vitamin, Calcium and iron group for collegiate athletes was higher than non- collegiate athletes. Since most athletes collegiate who attend a college degree in physical education; so sport nutrition, sport physiology or exercise science are some of the collegiate athlete's courses, we can consider passing these courses by collegiate athlete's as the reason of increasing their knowledge in comparison with a student of other fields. Achievements of these studies show that educational interferences will cause a growth of knowledge important for individual's attitude toward nutrition (Jessri et al., 2010; Rosenbloom et al., 2002). The results of present study also indicate that superiority of knowledge and attitude of collegiate athlete's in comparison with collegiate athletes will emphasize this idea too. Appropriate nutrition is very significant in important for social health. Main objective of nutrition schemes and programs is to achieve appropriate and sufficient 
nutrition in order to increase the health level. Since the advancement in level of knowledge, attitude and nutritional style of this majority of society can help to improve individual's nutritional knowledge and information to have a healthy society and is effective in decreasing the rate of problems related to health and diseases. Although sport nutrition education may benefit athletes, Iranian college and club entities are lacking in the sport-science and nutrition services needed to provide best-practice nutrition information to their athletes. Although most Iranian coaches are misinformed about nutrition science, they play the central role in training and educating athletes. Our results suggest that college athletes could benefit from nutrition courses at university as a cost-effective and accessible way of obtaining reputable nutritional information. These results also suggest that management personnel of sport teams could attempt to secure funding to contract with dietitians and nutritionists to provide best-practice current and relevant sport nutrition information to the team. Nutrition knowledge was found low for the collegiate and non-collegiate athlete; but, had lower nutrition knowledge in non-college athletes enrolled in sport campuses to become prospective teachers and coaches and they were not aware of the importance of the nutrition for performance. Enough and balanced nutrition should be a perfect life style and an eating habit for a sportsman. The number of courses related to nutrition should be increased in universities and sport campuses. The main objective in these courses should be to make the theoretical knowledge applicable in daily life. Experienced sportsmen and trainers should pursue ways to educate young people on how to select nutritious foods that will promote a lifetime of good health.

\section{CONCLUSIONS}

This study represents a first step in identifying the current nutrition knowledge and attitudes of collegiate and non-collegiate male and female athletes in Iran. Based on the result of our study the knowledge of Iranian non-college athletes is lower in comparison to college athletes, and these suggest that nutrition knowledge and attitudes of Iranian non-college athletes need to improve. So, improving a nutrition education program for non-college athlete could be an effective way to promote their nutrition knowledge and attitudes. The importance of nutrition and improvement of the learning environment, relate to nutrition need to be emphasized on sport campuses.

\section{ACKNOWLEDGMENTS}

The authors would like to acknowledge the research committee and university faculty members who reviewed the translated questionnaire, especially for their assistance in the conception of this research project. We gratefully acknowledge our study participants for the time they spent completing the questionnaires.

\section{REFERENCES}

Abood, D. A., Black, D. R., \& Birnbaum, R. D. (2004). Nutrition education intervention for college female athletes. Journal of Nutrition Education Behavior, 36, 135-139. doi: 10.1016/S14994046(06)60150-4

American College of Sports Medicine, American Dietetic Association, \& Dietitians of Canada. (2000). Nutrition and athletic performance. Medicine and Sport Science, 32(12), 2130-2145.

Azizi, M., Rahmani-Nia, F., Malaee, M., Malaee, M., \& Khosravi, N. (2010). A study of nutrition knowledge and attitudes of elite college athletes in Iran. Brazilian Journal of Biomotricity, 4(2), 105112.

Barr, S. I. (1987). Nutrition knowledge of female varsity athletes and university students. Journal of American Dietetic Association, 87, 1660-1664.

PMid: 3680825

Beals, K. A., \& Manore, M. M. (1998). Nutritional status of female athletes with subclinical eating disorders. I Am Diet Assoc, 98, 419-425. doi: 10.1016/S0002-8223(98)00096-0

Chang, S. L. (1987). Survey on health knowledge of college students in the middle area of Taiwan. Public Health, 14, 250-273.

Chapman, P., \& Toma, R. B. (1997). Nutrition knowledge among adolescent high school female athletes. Adolescence, 32, 437-446. PMid: 9179339

Cotugna, N., Vickery, C. E., \& McBee, S. (2005). Sports Nutrition for Young Athletes. The Journal of School Nursing, 21(6), 323-328. doi: 10.1177/ 10598405050210060401

Dunn, D., Turner, L. W., \& Denny, G. (2007). Nutrition knowledge and attitudes of college athletes. The Sport Journal, 10(4), 1-5.

Frederick, L., \& Hawkins, S. T. (1992). A comparison of nutrition knowledge and attitudes, dietary practices, and bone densities of postmenopausal women, female college athletes and nonathletic college women. Journal of American Dietetic Association, 92, 199-205. 
Georgia, S., Guldan, Y. W., Lin, Y., Zhao, M., Xiang, D. P., Yang, L., \& Long, F. (1993). Evaluation of a nutrition education activity for medical student in china. Asia Pacific J Clin Nutr, 2, 71-76.

Hassapidou, M. N., Fourtounopoulos, D., Efstratiou, E., Kitsou, S., \& Papakitsos, C. (2003). Dietary intakes of Greek basketball players. Nutrition and Food Science, 33, 23-27. doi: 10.1108/ 00346650310459536

Jacobson, B. H., Sobonya, C., \& Ransone, J. (2001). Nutrition practices and knowledge of college varsity athletes: A follow-up. Journal of Strength and Condidioning Research, 15, 63-68. doi: 10.1519/1533-4287(2001)015<0063:NPAKOC >2.0.CO;2; doi: 10.1519/00124278-20010200000011

Jessri, M., Jessri, M., RashidKhani, B., \& Zinn, C. (2010). Evaluation of Iranian College Athletes' Sport Nutrition Knowledge. International Journal of Sport Nutrition and Exercise Metabolism, 20, 257-263. PMid: 20601743

Kearney, J. M., \& McElhone, S. (1999). Perceived barriers in trying to eat health ierresults of a pan-EU consumer attitudinal survey. British Journal of Nutrition, 81(2), 133-137. doi: 10.1017/ S0007114599000987

Kunkel, M. E., Bell, L. B., \& Luccia, B. H. D. (2001). Peer nutrition education program to improve nutrition knowledge of female collegiate athletes. Journal of Nutrition Education, 33, 114115. doi: 10.1016/S1499-4046(06)60175-9

Laurie, G., Zawila, C., \& Steibt, B. (2003). The female collegiate cross-country runner: nutritional knowledge and attitudes. Journal of Atbletic Training, 38, 67-74.

Lin, W., \& Lee, Y. W. (2005). Nutrition knowledge, attitudes, and dietary restriction behavior of the Taiwanese elderly. Asia Pac J Clin Nutr, 14(3), 221-229. PMid: 16169832

Lissner, L., \& Heitmann, B. L. (1995). Dietary fat and obesity: evidence from epidemiology. European Journal of Clinical Nutrition, 49, 79-90. PMid: 7743988

Malinauskas, B. M., Overton, R. F., Cucchiara, A. J., Carpenter, A. B., \& Corbett, A. B. (2007). Summer league college baseball players: Do dietary intake and barriers to eating healthy differ between game and non-game days? The Sport Management and Related Topics Journal, 3(2), 23-34.

Mitchell, S. J. (1990). Changes after taking a college basic nutrition course. Journal of American Dietetic Association, 90, 955-961. PMid: 2365937
Nancy, C., Connie, E., Vickery, R. D., \& Mcbee, S. (2005). Sports Nutrition for Young Athletes. Journal of School Nurses, 21, 323-328. doi: $10.1177 / 10598405050210060401$

O'dea, J., \& Abraham, S. (2001). Knowledge, beliefs, attitudes, and behaviors related to weight control, eating disorders, and body image in Australian trainee home economics and physical education teachers. Journal of Nutrition Education, 33, 332-340. doi: 10.1016/S14994046(06)60355-2

Ozdoğan, Y., \& Ozcelik, A. O. (2011). Evaluation of the nutrition knowledge of sports department students of universities. Journal of the International Society of Sports Nutrition, 8, 11. doi: 10.1186/1550-2783-8-11; PMid: 21892942; PMCid: 3177873

Paschoal, V. C. P., \& Amancio, O. M. S. (2004). Nutritional status of Brazilian elite swimmers. International Journal of Sport Nutrition and Exercise Metabolism, 14, 81-94. PMid: 15129932

Read, M., \& Schlenker, E. D. (1993). Food selection patterns among the aged. In J. M. Smith (Ed.), Nutrition in Aging (pp. 45-53). 2nd ed. St. Louis, MO: Mosby Inc.

Rosenbloom, C. A., Jonnalagadda, S. S., \& Skinner, R. (2002). Nutrition knowledge of collegiate athletes in a division I national collegiate Athletic Association Institution. Journal of the American Dietetic Association, 102(3), 418-420. doi: 10.1016/S0002-8223(02)90098-2

Ruka, S., Toyama, K., Amamoto, R., Liu, C. H., \& Shinfuku, N. (2005). Nutritional knowledge, food habits and health attitude of Chinese university students-a cross sectional study. Journal of Nutrition, 4, 1475-1480.

Sakamaki, R., Toyama, K., Amamoto, R., Liu, C. H., \& Shinfuku, N. (2005). Nutritional knowledge, food habits and health attitude of Chinese university students - a cross sectional study. Nutrition Journal, 4(4), 1-5.

Schmalz, K. (1993). Nutrition beliefs and practices of adolescent athlete's. Journal of School Nurses, 9, 18-22. PMid: 8499690

Zawila, L. A., Steib, C. M., \& Hoogenboom, B. (2003). The female collegiate cross-country runner: Nutritional knowledge and attitudes. Journal of Athletic Training, 38(1) 67-74. PMid: 12937475; PMCid: 155514

Wiita, B., Stombaugh, I., \& Buch, J. (1995). Nutrition knowledge and eating practices of young female athletes. The Journal of Physical Education, Recreation, \& Dance, 66(3), 36-41. 
Y1lmaz, E., \& Özkan, S. (2007). Üniversite öğrencilerinin beslenme alışkanlıklarının incelenmesi [Examination of eating habits of university students]. Furat Sağllk Hizmetleri Dergisi, 2(6), 87104.

Yueching, W., \& Yi-Chia, H. (1999). Is the College environment adequate for accessing to nutrition education: A study in Taiwan? Nutrition Research, 19, 1327-1337.
Received: Septembr 6, 2012

Revision received: December 8, 2012

Accepted: December 11, 2012

Correspondence to:

Hamid Arazi, PhD

Department of Exercise Physiology, Faculty of Sport Sciences, University of Guilana P.O. Box: 41635-1438, Rasht, Iranl E-mail: hamidarazi@yahoo.com Phone: 